\title{
Sistem Pendukung Keputusan Bagi Penerima Bantuan Siswa Miskin (BSM) Menggunakan Metode Simple Additive Weighting (SAW) di SMA Negeri 1 Raren Batuah Kabupaten Barito Timur
}

\author{
Ebet Tri Cahyanu1 $^{1 *}$, Siska Dewi Lestari ${ }^{2 *}$, Herry Hermawan ${ }^{3 *}$ \\ * Manajemen Informatika, Politeknik Muara Teweh \\ ebet_tri@gmail.com ${ }^{1}$, siska.dewi@gmail.com², adeli4net@gmail.com ${ }^{3}$
}

\begin{tabular}{l}
\hline Article Info \\
\hline Article history: \\
Received 2019-11-16 \\
Revised 2019-12-04 \\
Accepted 2019-12-06 \\
\hline
\end{tabular}

Keyword:

Sistem Pendukung Keputusan, Bantuan Siswa Miskin, Simple Additive Weighting (SAW)

\begin{abstract}
SMA Raren Batuah 1 merupakan tingkat pendidikan sekolah menengah atas yang berlokasi di Desa Unsum, Kecamatan Raren Batuah, Kabupaten Barito Timur. SMA Raren Batuah 1 memiliki program bantuan dalam bentuk subsidi siswa miskin. Bantuan siswa miskin ini merupakan program yang menunjang terhadap kelancaran belajar mengajar. Proses seleksi penerima bantuan siswa miskin diperlukan sistem pendukung keputusan. Penelitian ini merancang sistem pendukung keputusan menggunakan metode Simple Additive Weighting (SAW) dengan memprioritaskan kriteria pendapatan orang tua, jumlah tanggungan orang tua, dan nilai rata - rata raport siswa. Penelitian ini mengembangkan aplikasi menggunakan bahasa pemrograman Microsoft Visual Basic.Net 2010. Hasil pengujian sistem dapat menampilkan daftar hasil perangkingan para calon penerima beasiswa berdasarkan urutan tertinggi hingga terendah sehingga akan memudahkan dalam proses pengambilan keputusan dalam seleksi penerima beasiswa Bantuan Siswa Miskin (BSM).
\end{abstract}

\section{Pendahuluan}

SMA Negeri 1 Raren Batuah merupakan jenjang pendidikan menengah atas setelah lulus dari Sekolah Menengah Pertama (SMP) atau yang sederajat, SMA Negeri 1 Raren Batuah beralamat pada Desa Unsum Kecamatan Raren Batuah Kabupaten Barito Timur (Jl. Ampah - Muara Teweh Km 14 Unsum). SMA Negeri 1 Raren Batuah bertujuan untuk menyediakan jenjang pendidikan tingkat menengah atas untuk Kecamatan Raren Batuah sehingga siswa/siswi yang lulus dari SMP yang berada di sekitar area Kecamatan Raren Batuah dapat melanjutkan pendidikan tanpa harus menempuh jarak yang lumayan jauh. Pada SMA Negeri 1 Raren Batuah sebagian besar siswa/ siswi yang bersekolah berasal dari keluarga yang kurang mampu, untuk itu diberikan bantuan subsidi bagi siswa/siswi. Bantuan subsidi tersebut bertujuan agar para siswa/siswi dapat melanjutkan dan memperoleh pendidikan yang layak serta mengurangi tingkat putus sekolah bagi siswa/siswi yang kurang mampu karena keterbatasan biaya. Bantuan Siswa Miskin (BSM) adalah bantuan dari pemerintah berupa sejumlah uang tunai yang diberikan secara langsung kepada siswa sesuai kriteria yang telah ditetapkan. Kriteria yang menentukan bahwa siswa/siswi tersebut benar-benar tidak mampu/miskin adalah dipandang dari minimnya jumlah penghasilan orang tua siswa, tempat tinggal, media transport (perjalanan) ke sekolah, jumlah saudara kandung serta nilai siswa yang bersangkutan.

Dalam upaya pemerataan kesempatan memperoleh pendidikan dan mutu pendidikan dan menekan angka putus sekolah pemerintah memperluas akses pendidikan yang lebih bermutu dan merata dengan memberikan perhatian yang lebih besar kepada penduduk miskin. Perhatian itu dalam bentuk program pemberian Bantuan Siswa Miskin (BSM) dan subsidi yang diberikan kepada siswa miskin disalurkan dari Anggaran Pendapatan dan Belanja Daerah (APBD) melalui Bank Kalteng.

Proses pemilihan penerimaan Bantuan Siswa Miskin (BSM) di SMA Negeri 1 Raren Batuah, dalam pengambilan keputusan sebelumnya menggunakan sistem yang belum menggunakan media komputer. Dalam menentukan keputusan calon penerima Bantuan Siswa Miskin (BSM) 
panitia harus mengumpulkan data seleksi calon penerima BSM dari data siswa yang berasal dari keluarga sederhana sampai kurang mampu. Hal ini menjadi sebuah kendala bagi panitia penerimaan BSM dalam proses pengambilan keputusan.

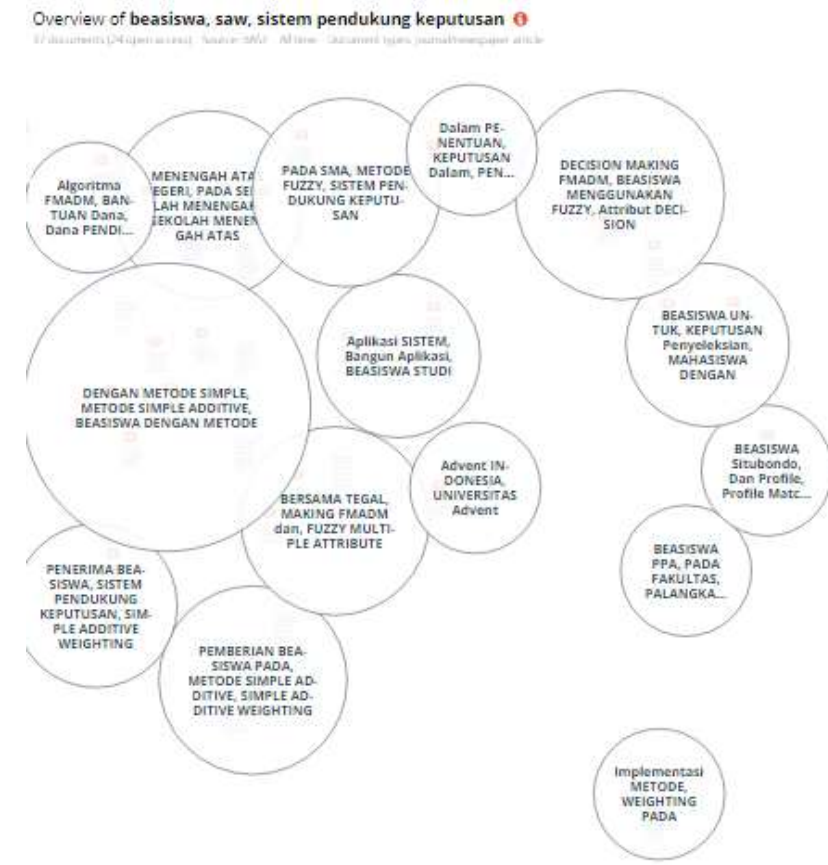

Gambar 1. Hasil penelitian terkait pada OpenKnowledgeMaps menggunakan basisdata BASE

Beberapa penelitian yang telah dilakukan diantaranya pemilihan kelayakan kredit [1] menghasilkan perangkingan nasabah untuk keputusan pemberian kredit, pemilihan pemasok/supplier [2] menghasilkan perangkingan terkait alternatif supplier yang tersedia, penentuan lokasi objek [3] [4] menghasilkan pemilihan suatu objek lokasi wisata dan perumahan menggunakan TOPSIS dan Weight Product, analisa Surat Peringatan (SP) siswa menggunakan AHP [5] menghasilkan pengetahun terhadap faktor yang berpengaruh terhadap permasalahan siswa. Selain itu sistem keputusan penerima beasiswa siswa SMA [6] menggunakan AHP, penerima beasiswa mahasiswa menggunakan TOPSIS [7] dan menggunakan SAW [8].

Berdasarkan penelitian tersebut maka peneliti mencoba melakukan penelitian terkait bagaimana implementasi sistem pendukung keputusan yang digunakan untuk pemilihan beasiswa yang berada pada SMA Negeri 1 Raren Batuah dalam program penerima Bantuan Siswa Miskin (BSM).

\section{Metode Penelitian}

Metode penelitian ini melakukan penelitian perancangan sistem yang diilustrasikan pada gambar 2. Flowchart aplikasi sistem pendukung keputusan penerima program bantuan beasiswa miskin pada SMA Negeri 1 Raren Batuah dirancang menggunakan bahasa pemrograman Microsoft Visual Basic.Net 2010

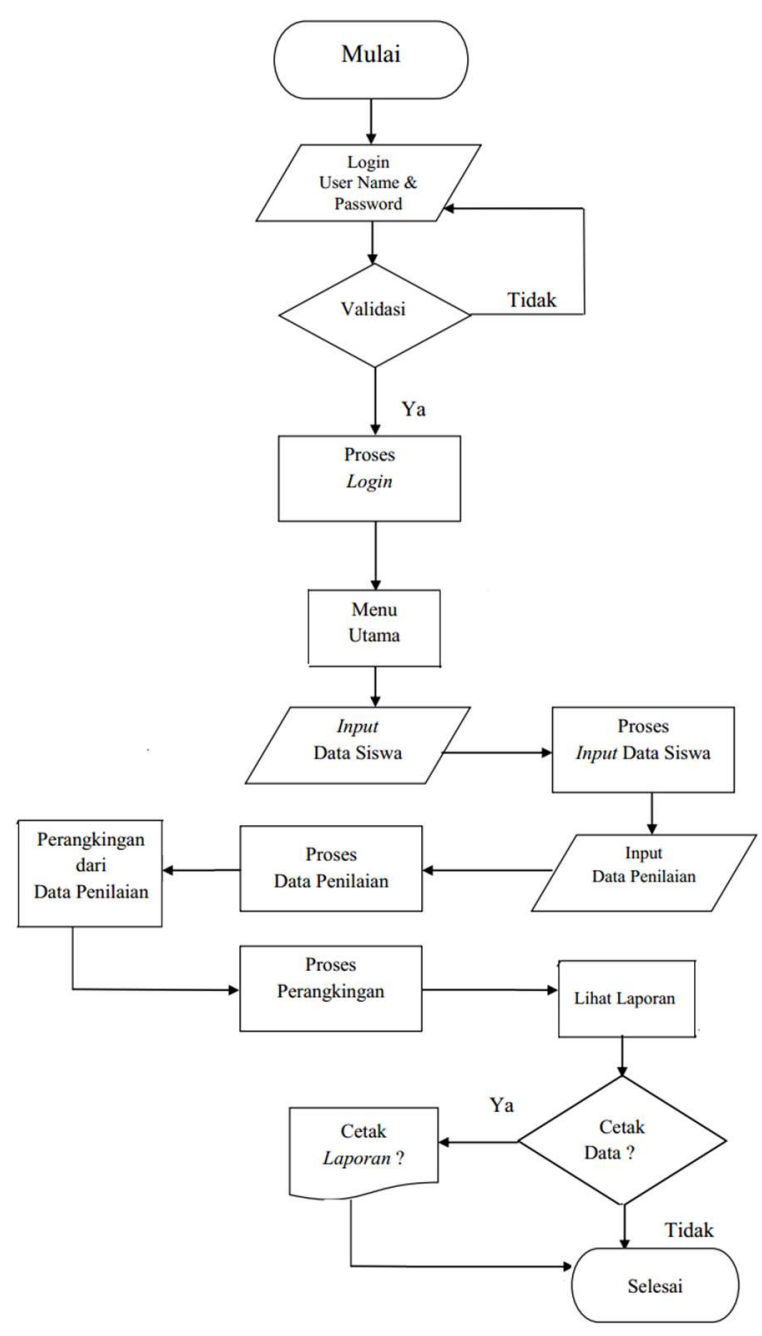

Gambar 2. Flowchart Sistem Pendukung Keputusan (SPK)

Gambar 2 merupakan flowchart sistem pendukung keputusan yang diimplementasikan. Terdapat aktor admin yang memiliki hak akses untuk login, input dan proses data siswa, input dan proses data penilaian serta perangkingan data nilai, proses perhitungan menggunakan Simple Aditive Weighting (SAW) untuk perangkingan data, lihat laporan data hasil perangkingan yang akan menjadi calon penerima beasiswa dan cetak laporan hasil perangkingan/penerima beasiswa tersebut. Metode SAW sering dikenal istilah metode penjumlahan terbobot [9]. Konsep dasar metode SAW adalah mencari penjumlahan terbobot dari rating kinerja pada setiap alternatif pada semua atribut [9] [10].

Metode SAW dapat membantu dalam pengambilan keputusan suatu kasus, akan tetapi perhitungan menggunakan ini hanya menghasilkan nilai terbesar yang akan terpilih sebagai alternatif terbaik. Perhitungan akan sesuai dengan metode ini apabila alternatif yang terpilih memenuhi kriteria yang telah ditentukan. Metode SAW ini lebih efisien karena waktu yang dibutuhkan dalam perhitungan lebih singkat. 
Metode SAW membutuhkan proses normalisasi matriks keputusan X ke suatu skala yang dapat diperbandingkan dengan semua rating alternatif yang ada. Formula untuk melakukan normalisasi tersebut adalah sebagai berikut [11].

$r_{i j}=\left\{\begin{array}{l}\frac{X_{i j}}{\operatorname{Max} X_{i j}} \\ \cdot{ }^{M i n} X_{i j} \\ X_{i j}\end{array}\right.$

Max Jika $j$ adalah atribut keuntungan (benefit)

Min Jika $\mathrm{j}$ adalah atribut biaya (cost)

Dimana $\mathrm{r}_{\mathrm{ij}}$ merupakan rating kinerja ternormalisasi dari alternatif $\mathrm{A}_{\mathrm{i}}(\mathrm{i}=, 2, \ldots, \mathrm{m})$. Max $\mathrm{i}=$ nilai maksimum dari setiap baris dan kolom. Min $i=$ nilai minimum dari setiap baris dan kolom $\mathrm{X}_{\mathrm{ij}}=$ baris dan kolom dari matriks. Formula untuk mencari nilai preferensi untuk setiap alternatif $\left(\mathrm{V}_{\mathrm{i}}\right)$ diberikan sebagai berikut [11].

$V_{i}=\sum_{j=1}^{n} W_{j} r_{i j}$

Dimana $\mathrm{V}_{\mathrm{i}}$ merupakan nilai akhir dari alternative, $\mathrm{W}_{\mathrm{i}}$ merupakan bobot yang telah ditentukan dan $\mathrm{r}_{\mathrm{ij}}$ merupakan normalisasi matriks. Nilai $\mathrm{V}_{\mathrm{i}}$ yang lebih besar mengindikasikan bahwa alternatif $\mathrm{A}_{\mathrm{i}}$ lebih terpilih.

Setelah mengetahui bagaimana metode SAW diimplementasikan berikutnya adalah melakukan perancangan diagram ERD (Entity Relation Diagram) digunakan untuk memodelkan data dan relasinya. ERD ini nanti digunakan dalam basisdata aplikasi yang dikembangkan.

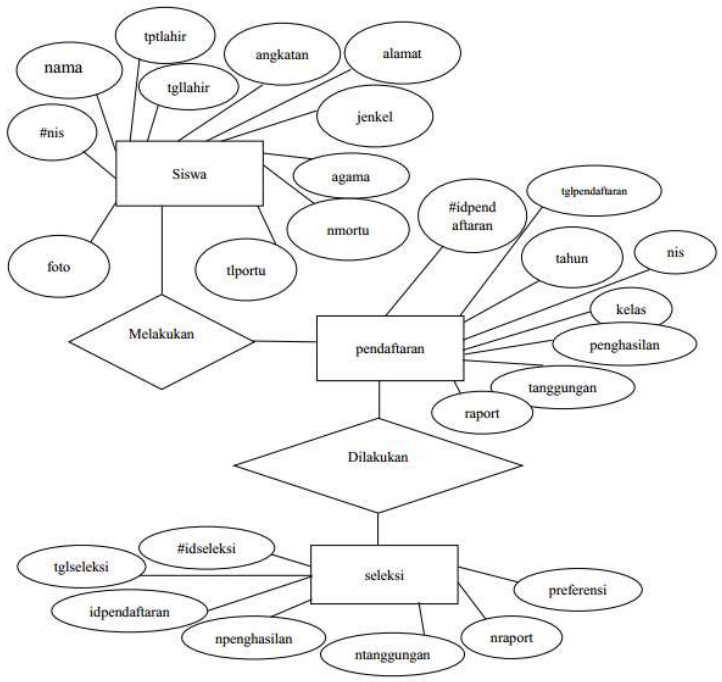

Gambar 4. ERD Sistem Pendukung Keputusan (SPK)

ER Diagram sistem yang dirancang memiliki 3 tabel utama yaitu tabel siswa, tabel pendaftaran dan tabel seleksi. Pada tabel siswa, memiliki 11 atribut yaitu nis sebagai primary key, Nama, Tmplahir, Tgllahir, Angkatan, Alamat, Jenkel, Agama, Nmortu, Telportu dan Foto. Pada tabel pendaftaran, memiliki 8 atribut yaitu Idpendaftaran sebagai primary key, Tglpendaftaran, Tahun, Nis, Kelas, Penghasilan, Tanggungan dan Raport. Pada tabel seleksi, memiliki 7 atribut yaitu Idseleksi sebagai primary key, tglseleksi, idpendaftaran, Npenghasilan, Ntanggungan, Nraport dan Referensi.

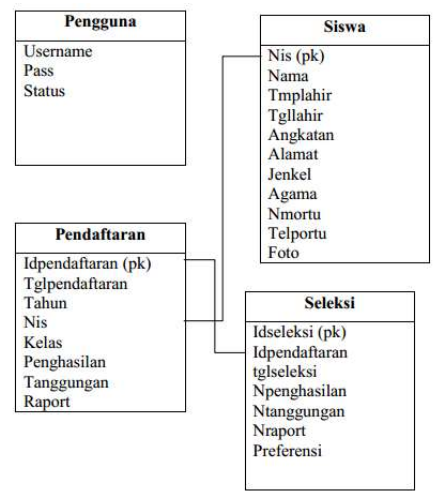

Gambar 5. Relasi antar Tabel Sistem Pendukung Keputusan (SPK)

Gambar 5 merupakan Relasi antar tabel dari aplikasi sistem pendukung keputusan penerima bantuan siswa miskin. Dimana pada table siswa, atribut Nis berelasi dengan atribut Nis yang ada pada table Pendaftaran, sedangkan atribut Idpendaftaran yang ada pada table Pendaftaran berelasi dengan atribut Idpendaftaran yang ada pada table Seleksi.

\section{HASIL DAN IMPLEMENTASI}

Implementasi dari Sistem Pendukung Keputusan Penerima Bantuan Siswa Miskin (BSM) meliputi input dan output, dimana input berupa pengisian data siswa dan data pendaftaran, output berupa laporan data siswa, laporan data pendaftaran serta hasil perhitungan menggunakan metode Simple Additive Weighting (SAW) dengan tahapan penghitungan penjumlahan terbobot. Pada SMA Negeri 1 Raren Batuah diberikan satu jatah untuk penerima bantuan siswa miskin sejumlah tiga orang siswa sebagai calon penerima. Adapun contoh data siswa yang mendaftar beasiswa penerima bantuan siswa miskin dapat dilihat pada Tabel I berikut disertai dengan bobot masing - masing kriteria.

TABEL I

Data Siswa Sman 1 RaRen Batuah Yang Mendaftar Beasiswa

\begin{tabular}{|c|l|r|c|c|}
\hline \multirow{2}{*}{ No } & \multirow{2}{*}{ Nama } & Bobot 50\% & Bobot 30\% & Bobot 20\% \\
\cline { 3 - 5 } & & Penghasilan & Tanggungan & $\begin{array}{l}\text { Nilai Rata- } \\
\text { rata }\end{array}$ \\
\hline 1 & Indra & 2.000 .000 & 4 & 80.00 \\
\hline 2 & Roni & 2.500 .000 & 3 & 80.22 \\
\hline 3 & Putri & 1.500 .000 & 3 & 75.50 \\
\hline 4 & Dani & 500.000 & 4 & 80.00 \\
\hline 5 & Ratna & 1.000 .000 & 5 & 85.00 \\
\hline 6 & Mira & 800.000 & 3 & 90.00 \\
\hline
\end{tabular}


Untuk menyelesaikan permasalahan ini maka dilakukan proses perhitungan seleksi menggunakan Metode SAW dengan memilih ada tiga kriteria yang digunakan untuk melakukan penilaian, yaitu:

- $\quad \mathrm{C} 1=$ Penghasilan

- $\mathrm{C} 2=$ Tanggungan

- $\quad \mathrm{C} 3=$ Nilai rata - rata

Pengambil keputusan memberikan bobot untuk setiap kriteria misalnya $\mathrm{C} 1=50 \%, \mathrm{C} 2=30 \%$, dan $\mathrm{C} 3=20 \%$. Pada table 1 terdapat enam orang siswa yang mendaftar menjadi calon penerima beasiswa (disebut sebagai alternatif), yaitu A1 = Indra, A2 = Roni, A3 = Putri, A4 = Dani, A5 = Ratna, A6 = Mira. Langkah penyelesaiannya adalah menentukan nilai Maksimal dan minimal dari masing - masing kriteria tersebut. Mencari nilai minimal dari penghasilan dengan melihat seluruh nilai penghasilan dari tabel I, nilai diperoleh dari nama siswa (Dani) dengan penghasilan sekitar 500.000, maka dari itu dapat disebut sebagai nilai minimal dari penghasilan. Kemudian mencari nilai maksimal dari kriteria tanggungan adalah dengan melihat dari total siswa yang mendaftar, tanggungan maksimal diperoleh dari siswa atas nama Ratna dengan jumlah tanggungan adalah 5.

Selanjutnya mencari nilai maksimal dari kriteria nilai rata-rata adalah dengan melihat dari total siswa yang mendaftar, nilai rata - rata maksimal diperoleh dari siswa atas nama (Mira) dengan jumlah nilai rata - rata adalah 90.00. Kemudian menentukan nilai normalisasi dari masingmasing kriteria. Untuk menentukan nilai normalisasi dari kriteria penghasilan adalah dengan cara nilai minimal yang diperoleh dari penghasilan dibagi dengan nilai kriteria penghasilan contohnya 500.000 (minimal penghasilan) dibagi dengan 2.000.000 (nilai penghasilan) maka akan diperoleh 0,25 sebagai nilai normalisasi, demikian dengan seterusnya.

Untuk menentukan nilai normalisasi dari tanggungan adalah dengan cara nilai kriteria tanggungan dibagi dengan nilai maksimal yang diperoleh dari kriteria tanggungan, contohnya 5 (maksimal tanggungan) dibagi dengan 4 (nilai tanggungan) maka akan diperoleh 0,80 sebagai nilai normalisasi, demikian dengan seterusnya.

Untuk menentukan nilai normalisasi dari nilai rata-rata adalah dengan cara nilai kriteria nilai rata-rata dibagi dengan nilai maksimal yang diperoleh dari kriteria nilai rata-rata, contohnya 90 (maksimal nilai rata-rata) dibagi 80 (nilai ratarata) maka akan diperoleh 0,89 sebagai nilai normalisasi, demikian dengan seterusnya.

Untuk menentukan nilai preferensi yang akan digunakan sebagai acuan pengambilan keputusan adalah dengan cara menjumlahkan seluruh nilai normalisasi yang sudah dikali dengan bobot masing - masing, contohnya $(0,25 \times 50 \%)+$ $(0,80 \times 30 \%)+(0,89 \times 20 \%)=0,54$, demikian dengan seterusnya.

Tahapan terakhir adalah melakukan seleksi untuk mengambil sebuah keputusan dengan cara melihat seluruh nilai preferensi dan mengurutkan berdasarkan nilai preferensi terbesar. Nilai terbesar ada pada siswa atas nama
Dani sehingga terpilih sebagai alternatif pertama dan seterusnya. Dengan kata lain, siswa atas nama Dani akan terpilih sebagai penerima bantuan siswa miskin di SMA Negeri 1 Raren Batuah. Perhitungan tersebut secara keseluruhan dapat dilihat pada table 2 berikut.

TABEL II

HAsil SEleKsi PENERIMA BEASISWA

\begin{tabular}{|c|l|c|c|c|c|}
\hline \multirow{2}{*}{ No } & \multirow{2}{*}{ Nama } & \multicolumn{3}{|c|}{ Normalisasi } & \multirow{2}{*}{ Referensi } \\
\cline { 3 - 5 } & & Penghasilan & Tanggungan & Nilai & \\
\hline 1 & Dani & 1.00 & 0.80 & 0.89 & 0.92 \\
\hline 2 & Ratna & 0.50 & 1.00 & 0.94 & 0.74 \\
\hline 3 & Mira & 0.63 & 0.60 & 1.00 & 0.69 \\
\hline 4 & Indra & 0.25 & 0.80 & 0.89 & 0.54 \\
\hline 5 & Putri & 0.33 & 0.60 & 0.84 & 0.51 \\
\hline 6 & Roni & 0.20 & 0.60 & 0.89 & 0.46 \\
\hline
\end{tabular}

Seluruh tahapan tersebut diformulasikan ke dalam bahasa pemograman untuk dapat ditampilkan ke dalam bentuk tampilan antar muka aplikasi yang lebih baik. Berikut beberapa hasil antarmuka aplikasi yang telah dikembangkan diantaranya form login, menu utama, data siswa, pendaftaran beasiswa, seleksi beasiswa, dan laporan beasiswa.

Form Login merupakan halaman yang digunakan untuk masuk ke dalam Aplikasi Sistem Pendukung Keputusan Bagi Penerima Bantuan Siswa Miskin (BSM) Menggunakan Metode Simple Additive Weighting (SAW) Di SMA Negeri 1 Raren Batuah Kabupaten Barito Timur. Jika username dan password benar, maka pengguna akan masuk ke dalam halaman Menu Utama. Jika salah, maka pengguna harus kembali memasukkan username dan password sampai benar.

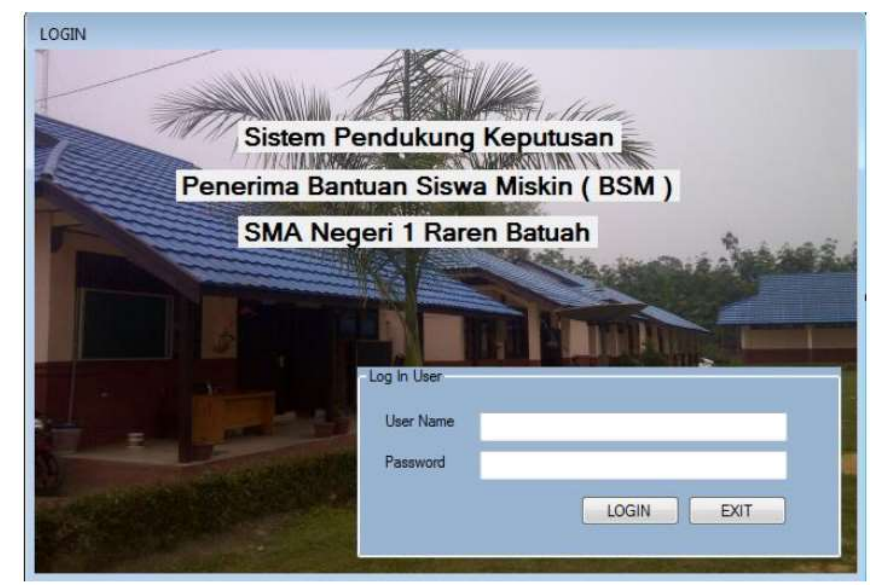

Gambar 6. Form Login

Halaman Menu Utama merupakan tampilan awal dari Aplikasi Sistem Pendukung Keputusan Bagi Penerima Bantuan Siswa Miskin (BSM) Menggunakan Metode Simple Additive Weighting (SAW) Di SMA Negeri 1 Raren Batuah Kabupaten Barito Timur. 


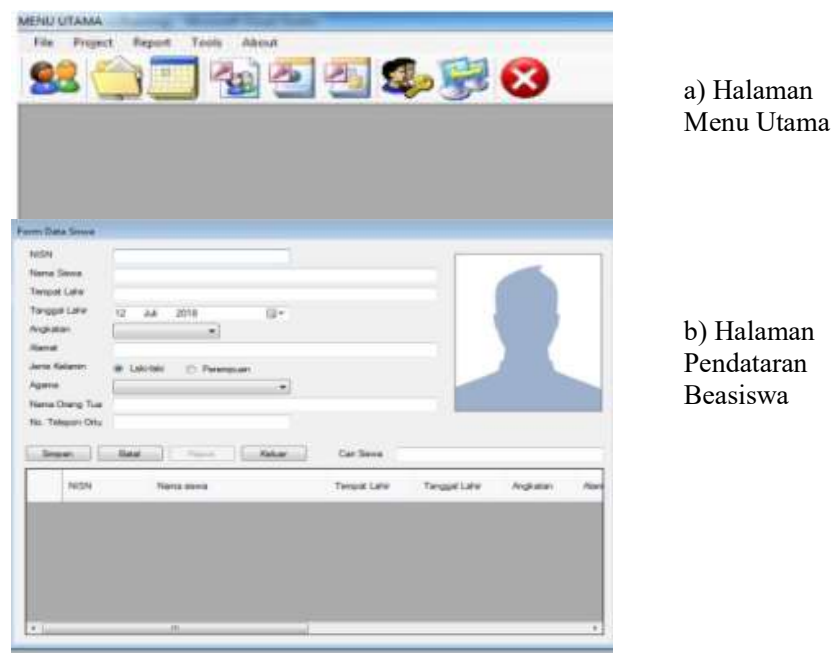

Gambar 7. Halaman Menu Utama dan Pendaftaran Beasiswa

Gambar 7 merupakan Halaman Data Siswa yang merupakan halaman untuk menginput data siswa SMA Negeri 1 Raren Batuah Kabupaten Barito Timur. Halaman Pendaftaran Beasiswa merupakan halaman yang digunakan untuk menginput data siswa SMA Negeri 1 Raren Batuah Kabupaten Barito Timur yang ingin mendapatkan Beasiswa Bantuan Siswa Miskin (BSM). Halaman Seleksi Beasiswa digunakan untuk melakukan seleksi/perangkingan data pendaftaran beasiswa dengan menggunakan Metode Simple Additive Weighting (SAW). Setelah proses seleksi beasiswa selesai maka sistem akan menampilkan hasil dari perangkingan para calon penerima beasiswa berdasarkan rangking tertinggi.

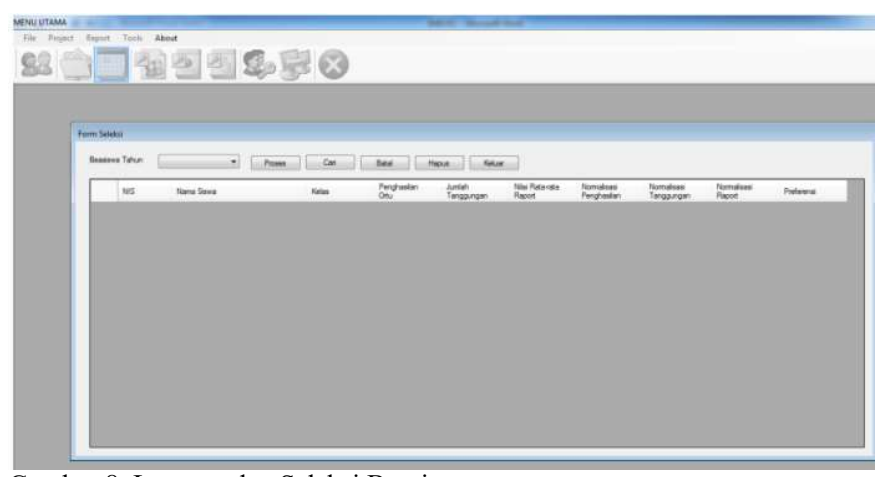

Gambar 8. Laporan dan Seleksi Beasiswa

Gambar 8 merupakan Form laporan data siswa digunakan untuk menampilkan laporan data siswa yang telah diisi. Form laporan pendaftaran beasiswa digunakan untuk menampilkan laporan data pendaftaran beasiswa yang telah diisi pada form data pendaftaran beasiswa. Form laporan seleksi digunakan untuk menampilkan laporan data seleksi yang telah dilakukan perangkingan/seleksi.

\section{KESIMPULAN}

Aplikasi Sistem Pendukung Keputusan Bagi Penerima Bantuan Siswa Miskin (BSM) Menggunakan Metode Simple
Additive Weighting (SAW) di SMA Negeri 1 Raren Batuah Kabupaten Barito Timur ini merupakan aplikasi yang dirancang khusus untuk mengetahui siswa yang berhak mendapatkan beasiswa Bantuan Siswa Miskin (BSM) berdasarkan beberapa kriteria seperti nilai dari penghasilan orang tua siswa, jumlah tanggungan/jumlah saudara kandung siswa, dan nilai rata-rata raport. Output yang dihasilkan dari berupa daftar hasil dari seleksi/perangkingan para calon penerima beasiswa berdasarkan rangking tertinggi sehingga akan memudahkan dalam mengambil keputusan penerima beasiswa Bantuan Siswa Miskin (BSM).

\section{UCAPAN TERIMA KASIH}

Penulis mengucapkan terima kasih kepada Dosen Pembimbing Politeknik Muara Teweh Program Studi Manajemen Informatika yang telah membantu dalam menyelesaikan penelitian ini.

\section{DAFTAR PUSTAKA}

[1] A. Wibowo and K. Kunendra, "Sistem Pendukung Keputusan Penilaian Kelayakan Kredit Menggunakan Metode Simple Additive Weighting (SAW)", J. Appl. Informatics Comput., vol. 1, no. 1, pp. 22-25, Dec. 2018.

[2] D. E. Kurniawan, P. Pujiyono, 'Sistem Pendukung Keputusan Pemilihan Pemasok Bahan Baku Menggunakan Metode Technique for Order Preference by Similarity to Ideal Solution', J. Integr., vol. 8, no. 1, pp. 56-60, Apr. 2016.

[3] D. E. Kurniawan and S. T. Amanda, 'Pemilihan Rumah Menggunakan Metode Weight Product Dengan Visualisasi Lokasi Objek', Klik - Kumpul. J. Ilmu Komput., vol. 4, no. 1, p. 102, Feb. 2017.

[4] D. E. Kurniawan, 'Pemilihan Wisata Menggunakan Technique for Order Preference By Similarity To Ideal Solution (Topsis) Dengan Visualisasi Lokasi Objek', Klik - Kumpul. J. Ilmu Komput., vol. 5, no. 1, p. 75,2018

[5] Y. Rokhayati, U. H. B. Rusdi, D. E. Kurniawan, N. Z. Janah, and S. Irawan, 'Analysis of SP Students Using AHP-Apriori Combination BT - International Conference On Applied Science and Technology 2019 - Social Sciences Track (iCASTSS 2019)', 2019.

[6] Y. Irawan, "Sistem Pendukung Keputusan Penentuan Penerimaan Beasiswa Berbasis Web SMA Islam Darul Huda Menggunakan Metode Analytical Hierarchy Process (AHP)", Jurnal Ilmu Komputer, vol. 7, no. 1, pp. 1-6, 2018. Available: 10.33060/jik/2018/vol7.iss1.74.

[7] M. Ismail, "Sistem Pendukung Keputusan Seleksi Penerimaan Mahasiswa Baru Jalur Beasiswa Dengan Metode Topsis (Technique For Order Preference By Similarity To Ideal Solution)", JIKO (Jurnal Informatika dan Komputer), vol. 3, no. 1, p. 1, 2018. Available: 10.26798/jiko.2018.v3i1.79.

[8] Y. Agassi V, I. Dharma W and R. Romlah, "Sistem Pendukung Keputusan Penerimaan Beasiswa Dengan Metode Simple Additive Weighting (SAW) di Politeknik Negeri Malang", Jurnal Informatika Polinema, vol. 1, no. 1, p. 53, 2014. Available: 10.33795/jip.v1i1.91.

[9] S. Kusumadewi and I. Guswaludin, "Fuzzy Multi-Criteria Decision Making", Media Informatika, vol. 3, no. 1, pp. 25-38, 2005. Available: 10.20885/informatika.vol3.iss1.art3.

[10] B. Christioko, H. Indriyawati and N. Hidayati, "Fuzzy Multi-Atribute Decision Making (Fuzzy MADM) Dengan Metode SAW Untuk Pemilihan Mahasiswa Berprestasi", 2019.

[11] Kusumadewi, S., Hartati, S., Harjoko, A., \& Wardoyo, R. (2006). Fuzzy Multi-Attribute Decision Making (Fuzzy MADM). Yogyakarta: Graha Ilmu, 78-79. 